\title{
Corporate Social Disclosure Practices in Kuwait
}

\author{
Mahammed Al-Ajmi ${ }^{1}$, Abdullah Al-Mutairi ${ }^{1}$ \& Nabi Al-Duwaila ${ }^{2}$ \\ ${ }^{1}$ Arab Open University, Kuwait branch, Kuwait \\ ${ }^{2}$ Public Authority for Applied Education and Training, Kuwait \\ Correspondence: Abdullah AL-Mutairi, Department of Business Administration, Arab Open University, Kuwait \\ Branch, Kuwait. E-mail: Drabdulla2011@ hotmail.com
}

Received: June 11, 2015

Accepted: June 23, 2015

Online Published: August 25, 2015

doi:10.5539/ijef.v7n9p244

URL: http://dx.doi.org/10.5539/ijef.v7n9p244

\begin{abstract}
The purpose of this research is set out to examine the firm social responsibility disclosure practices in Kuwait by analyzing 2012 annual reports of industrial and service firms listed on Kuwait Stock Exchange (KSE) to find out whether the level of social disclosure is influenced by firm-specific characteristics. The study showed that the majority of the firms somehow disclose social information and revealed that the level of firm social responsibility disclosure is influenced by firm size, profitability and the government ownership. The study also demonstrated that social responsibility disclosure has a significant positive association with both firm size and profitability and negative marginal association with government ownership. Moreover, the study confirmed that other variables such as leverage; liquidity, firm age and type of industry have no significant impact on the social responsibility disclosure on industrial and service firms listed on KSE. The study concluded that the time has come for firms listed on KSE to do serious activities towards developing socialresponsibility disclosure.
\end{abstract}

Keywords: social disclosure, social responsibility accounting annual reports, firm-specific characteristics, Kuwait

\section{Introduction}

Social accounting has been subject of growing theoretical and empirical investigations in developed countries. The central issue in this literature is to examine whether there is a relationship between the level of social disclosure and firm-specific characteristics.

Empirical studies have shown that firms are disclosing social information in their annual reports and this has increased over years. It is shown that firms are making efforts to provide social information on a voluntary basis, which are mostly qualitative in nature. They also demonstrate that the level of social and environmental disclosure is influenced by firm-specific characteristics. These finding, however, seems to be questionable for the markets where government control over major economic activities such as the Gulf Co-operation Council (GCC) countries.

The purpose of the study is to examine the social disclosure practicesin Kuwait by analyzing annual reports of manufacturing and service listed firms on Kuwait Stock Exchange (KSE) to find out the impact of firm-specific characteristics on the level of social disclosure. KSE is of interest since it is one of the leading markets in the GCC region which is rich and open market with some initiative reforms. The current study is expected to be appreciated by government, professional institutes and researchers. For government, it might help put in place suitable legislation for all firms to compel them to make adequate disclosure of their activities to the society. For professional institutes, it might help to develop social accounting and reporting techniques in the areas of employment opportunities, environmental control and energy conservation. It helps to provide the basis and means of social accounting quantification to researchers.

The remainder of this study is organized as follows. In the next section, brief review of related literature and previous studies are presented. The third section presents data collection and model development. The findings and analysis are offered in section four. The paper ends with a conclusion.

\section{Related Literature and Previous Studies}

In accounting, the role of information and disclosure refer to three widely accounting theories namely legitimacy theory, stakeholder theory and institutional theory. Legitimacy theory assumes that the firms have contract with 
the society as a whole (Dowling \& Pfeffer, 1975). It is moral obligation of the firm to meet the expectations of the societal members (Ahmad \& Sulaiman, 2004). According to Deegan and Jeffry (2006) if the firm reaches the expectations of the society then it would be considered as legitimate otherwise its legitimacy would be at risk. Stakeholder theorydivides the society into groups called stakeholders. Stakeholders of the firm can be defined as any interest group who can be influenced by the performance of the firm. Therefore, according to stakeholder theory, there are two branches namely perspective branch and managerial perspective. The normative one treats all the stakeholders of the firm similarly and does not take into consideration any power of each stakeholder (Deegan \& Jeffry, 2006) while the managerial perspective takes into account the interests of limited number of stakeholders, who have significant power to influence the organization (Ullmann, 1985).

Institutional theory attempts to link organisation practices to societal values and tend towards homogeneity (Deegan \& Jeffry, 2006). It helps to structure the analysis; its usefulness and completeness is then reflected back upon. These three theoretical perspectives have been used by several academic researchers in recent times to clarify the relationships between the disclosure and the organizations.

In empirical literature, the studies of social disclosures were taken various places (Note 1). They demonstrated that the level of social disclosure is influenced by firm-specific characteristics. They also showed that firms are making efforts to provide social information on a voluntary basis.

Abu-Baker (2000) examined the role of corporate social disclosure practices in Jordan. He found that there are significant differences among the various industry groupings with respect to the amounts, methods and locations. This finding is confirmed by Ahmad et al. (2003), Ayadi (2004) in France, Rizk et al. (2008) in Egypt, Ismail and Ibrahim (2009) in Jordan, Echave and Bhati (2010) in Spain, Papaspyropoulos et al. (2010) in Greece, Uwalomwa and Uadiale (2011) in Nigeria, Bayoud et al. (2012) in Libya; Wang et al. (2012) in Taiwan, Suttipun and Stanton (2012) in Thailand.

Barnard (2000) examined the relationship between the firm's size and the level of social disclosure. He provided evidence that the firm size is associated with the extent of social disclosure. Barnard observed that larger companies have a greater tendency to report social information than smaller companies. This finding is confirmed by Al-Khadash (2004), Motta (2003) Huafang and Jianguo (2007), Ismail and Ibrahim (2009), Papaspyropoulos et al. (2010) Al-Farah and Al-Hindawi (2011), Alawi and Rahman (2011), Galani et al. (2011), AL-Shubiri et al. (2012), Uwuigbe (2012), Desoky and Mousa (2012), Setyorini and Ishak (2012), Andrikopoulos and Kriklani (2013), Akrout and Othman (2013).

Hossain et al. (2006) examined the relationship between the firm's profitability and the level of social disclosure. They found that firms with higher profitability tend to disclose more social information. This finding is confirmed by Joshi et al. (2011), Alawi and Rahman (2011), Lassaad and Khamoussi (2012), Hussainey et al. (2011), Setyorini and Ishak (2012), Andrikopoulos and Kriklani (2013).

Abu-Baker concluded that social disclosure needs much more attention by management. This finding is confirmed by Elijido-Ten (2004) in Malaysian firms; Haque (2012) in Bangladesh, Joshi et al. (2011) in India, Alawi and Rahman (2011) in Yemen, Zamir et al. (2011) in Pakistan, Uwuigbe (2012) and Uwuigbe and Jimoh (2012) in Nigeria, Binh (2012) in Vietnam, Desoky and Mousa (2012) in Egypt, Mbekomize and Dima (2013) in Botswana.

As far as the GCC region is concerned, few studies have been conducted to examine the corporate social disclosure practices (Note 2). The following section is a brief review of the above empirical studies.

Gibbon and Joshi (1999) found that firms in Bahrain are environmentally sensitive and they prepare environmental reporting for management requirements. The researchers observed that firms in Bahrain are not performing environmental accounting for external purposes. Gibbon and Joshi concluded that accountants and management of firms are likely to be less than objective in their environmental related disclosure practices in future. Juhmani (2014) found that the majority of the firms provides social information in their 2012 annual reports. He observed that there is significant relationship between firm's financial leverage and firm size with the level of social information disclosure.

Jahamani (2003) compared between the environmental disclosures in UAE and Jordan. He found that corporate decision-makers are aware of environment protection issues, but their commitment to environment protection is still low. Rettab et al. (2009) found that corporate social responsibility (CSR) has a positive relationship with all three measures of organisational performance: financial performance, employee commitment, and corporate reputation. Ahmed (2012) observed that the firm size, age, experience of managers, and regulatory requirements have major influence on the quantity and nature of social disclosure. 
Saaydah (2005) examined the extent of corporate social disclosures in Jordan, Bahrain and Kuwait. He provided evidence that there are differences among countries in human resource field of Total Corporate Social Disclosures (TCSD). He found that there is a positive relationship between TCSD and the firm size and net profit. He also found that there is no relationship between TCSD and corporate age, auditor type and industry. Saaydah provided evidence that government influence in the form of legislated disclosure requirements is more effective than direct stock ownership in convincing firms to act responsibly and disclose more social information about their activities.This findings are confirmed by Khasharmeh and Suwaidan (2010).

Naser et al. (2006) examined empirically the determinants of corporate social disclosure practices of 21 listed firms of Doha Securities Market (DSM) in Qatar. They found that there is a positive relationship between level of social disclosure and firm's size measured by the firm's market capitalization, business risk measured by leverage and corporate profit. Hossain and Hammami (2009) used 25 firms listed of DSM to examine the determinants of voluntary disclosure in the annual reports. They found that firm age, size, complexity and assets-in-place are significant. However, they observed that profitability variable is not significant with voluntary disclosure in the annual reports.

Al-Shammari (2008) examined the relationship between the level of voluntary disclosure and the firm features of 82 non-financial firms listed in KSE. He found that there is a positive relationship between the disclosure of social responsibility information and the firm's size. Al-Shammari concluded that Kuwaiti firms disclose significantly more corporate environment and social responsibility than financial disclosure. Furthermore, Alenezi (2011) used 119listed firms on KSE to examine the level of voluntary disclosure practices in Kuwait. He provided evidence that the cross-directorships, firm size, firm age are the most important variables explaining the voluntary disclosure of Kuwaiti firms.

Macarulla and Talalweh (2012) examined empirically the determinants of corporate social disclosure practices of Saudi firms. They found that the level of CSR disclosure is fairly low. They also found that firm size is the main variable linked to all CSR categories. Macarulla and Talalw observed that economic sector and profitability play important role in determining the level of CSR disclosure. Alturki (2014) examined the voluntary financial disclosure practices of Saudi corporations. They found that firm size, profitability, and listing age have significant positive association with voluntary disclosure level in annual reports. They also found that auditor size and leverage do not have any significant association with voluntary disclosure level.

It is evident that a limited number of empirical studies have been conducted to explain the social disclosure practices in GCC region. This suggests the need for additional empirical testing. Therefore, the current research was undertaken.

\section{Study Methodology}

To measure the level of corporate social disclosure by firms listed on KSE, content analysis was conducted on 2012 annual reports of these firms. The total number of firms listed on KSE was 211 at the end of 2012.

The 2012 annual reports of all industrial and service firms were employed to present evidence on the level and determinants of corporate social responsibility reporting in Kuwait by executing content analysis (Abu-Baker, 2000). It is worth mentioned that content analysis is a common in accounting research (Ismail \& Ibrahim, 2009). Annual reports were examined for details regard to five particular subjects of corporate social disclosure namely environment, energy, human resources, products and customers and community.

A disclosure index was used as a benchmark to determine the level of social disclosure by the firms listed on KSE. It is worth to be mentioned that a disclosure index was piloted by the researchers on a number of the firms' annual reports after designing its items. According to researchers' inspection, some of these items were excluded. Therefore, the disclosure index was modified to contain 15 items and to employ the un-weighted disclosure index. In other words, the firm score of ' 1 ' was awarded for the firm if an information item has been disclosed in its annual report, and ' 0 ' score was awarded if the item is not disclosed. The disclosure index for firm X will be as follows:

$$
\operatorname{CSRS}(x)=\sum_{t=0}^{n} I(x)
$$

Where,

CSRS (x) Corporate Social Responsibility Score for firm X;

I(x) Firm X Score for the Disclosure Item where 1 score is given for disclosure, and 0 score for non disclosure. 
Thus, the un-weighted corporate social disclosure index $(\operatorname{CSDI}(\mathrm{x}))$ of firm $\mathrm{X}$ is estimated by dividing its score (CSRS $(\mathrm{x}))$ over the maximum score (15) as follows.

$$
\operatorname{CSRS}(X)=\left(\frac{\operatorname{CSRS}(X)}{15}\right)
$$

The relationship between the level of corporate social disclosure and the firm's attributes is estimated by using the following regression model:

$$
C S E D=a+\beta_{1} S I Z E+\beta_{2} O W N+\beta_{3} I N D+\beta_{4} P R O F+\beta_{5} L I Q+\beta_{6} A G E+\beta_{7} L E V+E
$$

Where:

$\operatorname{CSRSI}(\mathrm{x})=$ Corporate social responsibility index scored by firm X;

$\mathrm{A}=$ Intercept;

SIZE $=$ Size measure by the logarithm total sales;

OWN = Percentage of government ownership in a firm;

IND = "1" if it is a manufacturing firm, and " 0 " if a service firm;

PROF $=$ Profitability measured by net income over sales;

LIQ = Liquidity = Current Assets / Current liabilities;

$\mathrm{AGE}=$ Number of years of the firm being working;

LEV $=$ Leverage $=$ Total Liabilities $/$ Total Assets;

$\mathrm{E}=$ Standard Error;

$\beta 1-\beta 7=$ Parameters of the model.

\section{Finding and Analysis}

\subsection{Descriptive Statistic}

Table 1 demonstrates the descriptive statistics of variables employed in this study. It shows that firms listed on KSE differ in their attributes. The mean score of the firm' social responsibility disclosure was 0.49 . It ranges between 0.4 up to 0.8 . It is obvious that there is variation in the level of corporate social responsibility disclosure among these firms. Table 1 also shows that the mean of all firms' profitability reached 0.43 and ranges from-5.7 Kuwaiti diner (KD) million to $216 \mathrm{KD}$ million.

Table 1 also reveals high variation in the percentage of shares owned by the government among the surveyed. It is appeared that while in some firms, the government ownership is as low as 0 percent, in other firms it goes up to reach 68 percent.

Table 1. Descriptive statistics about variables employed in the study

\begin{tabular}{ccccc}
\hline Variables & Min & Max & Mean & SD. \\
\hline CSRI & .4 & .8 & .49 & .11 \\
SIZE & 5.6 & 8.8 & 7.6 & .66 \\
OWN & .0 & .68 & .55 & .11 \\
PROF & -5.7 & 216 & 8 & 27 \\
AGE & 7 & 60 & 25.5 & 13.5 \\
LEV & .04 & 5.95 & .43 & .48 \\
LIQ & .15 & 23 & 2.6 & 3.5 \\
\hline
\end{tabular}

Furthermore, table 1 shows that there is a high variation in firms' age among the firms listed in KSE. It ranges from 7 to 60 years old for the firm's age. The variation among the firms is clear in their leverage and size represented by total sales.

It is clear that there is a wide range of variation within the sample indicated by the minimum and maximum values. Also, this table indicates that the firms examined in this study are large and important to the economy of Kuwait. This variation in the level of corporate social responsibility disclosure and the firms' attributes on KSE provides great opportunity for investigation. 


\subsection{Correlation}

Table 2 demonstrates the relationship among variables used in this study and to examine the multicollinearity among the independent variables, the Pearson correlation coefficient was conducted. It is obvious that corporate social responsibility index is positively and significantly associated with the percentage of shares owned by the government, firm's profit and size.

Table 2. Pearson correlation among variables used in the study

\begin{tabular}{cccccccc}
\hline Items & CSEI & SIZE & PROF & LIQ & LEV & AGE & OWN \\
\hline CSRI & 1 & & & & & & \\
SIZE & .003 & 1 & & & & & \\
PROF & .163 & $-.239^{*}$ & 1 & & & & \\
LIQ & $-.268^{*}$ & $-.244^{*}$ & -.108 & 1 & & & \\
LEV & $.221^{*}$ & .044 & -.027 & $-.293^{*}$ & 1 & & \\
AGE & -.009 & -.028 & .037 & -.175 & $.226^{*}$ & 1 & \\
OWN & .075 & -.081 & $.249^{*}$ & .041 & -.113 & -.147 & 1 \\
\hline
\end{tabular}

Note. *Correlation is significant at the 0.05 level (2-tailed).

It is appeared that there is negative correlation between firm's size and firm's profit and liquidity. Also, there is a negative correlation between firm's liquidity and firm's leverage and age. Furthermore, there is a positive correlation between firm's leverage and firm's age. It is worth to be mentioned that none of these correlations reached the critical value of 0.80 suggesting that multicollinearity is not a serious problem (Naser \& Hassan, 2013).

Moreover, the Variance Inflation Factor (VIF) for each of the independent variables was conducted to test the degree of multicollinearity of an independent variable with the other independent variables in a regression model. It is appeared that collinearity is not a problem in the regression model.

\subsection{Regression Analysis}

Table 3 shows the regression analysis of the relationship between the firm' social responsibility disclosure and the firm's attributes of industrial and service firms listed on KSE. It reveals that the F-ratio is $3.711(\mathrm{p}=0.002)$ and the adjusted $R^{2}$ is 0.213 which suggests that independent variables explain 21 percent of the variance in social responsibility disclosure index.

Table 3. Results of regression analysis

\begin{tabular}{cccll}
\hline C & Beta & T & Sig & VIF \\
\hline & .093 & 1.175 & .244 & \\
SIZE & .021 & 2.179 & .033 & 1.193 \\
PROF & .001 & 3.558 & .001 & 1.161 \\
LIQ & $-.001-$ & $-.507-$ & .614 & 1.281 \\
LEV & .020 & 1.355 & .180 & 1.144 \\
AGE & .000 & .949 & .346 & 1.190 \\
OWN & -.111 & -1.781 & .080 & 1.111 \\
IND & .005 & .310 & .310 & 1.119 \\
\hline
\end{tabular}

Notes. $\mathrm{R}^{2}=0.292 ;$ Adjusted $\mathrm{R}^{2}=0.213 ;$ F-statistic $=3.711 ;$ and Prob (F-statistics) $=0.002$.

It is obvious from table 3 that there is a significant and positive relationship between the level of social responsibility reporting and firm size represented by total sales. It reveals that large firms in terms of sales disclose more corporate social responsibility disclosure compared to small firms.The possible explanation for this finding is attributed to the fact that large firms in terms of sales are closely observed by many stakeholders, and they have the ability to realize extra costs for improved disclosure.

According to Owusu-Ansah (1998) small firms may not be able to afford the cost of accumulating and generating certain information. Moreover, large firms often have plenty sources for submitting massive quantity of information at minimum charge. Watts and Zimmerman (1983) demonstrated that large firms disclose more 
than small firms to reduce the potential agency cost. This finding is consistent with the results reached by previous empirical studies that reported firm size is an indicator for increase the level of corporate social responsibility disclosure such as Barnard (2000) in South Africa, Motta (2003) in Brazil, Al-Khadash (2004) and AL-Shubiri et al. (2012) in Jordan; Saaydah (2005) in Bahrain; Hossain and Hammami (2009) in Qatar; Galani et al. (2011) in Greece; Ebimobowei (2011) in Nigeria; Suttipun and Stanton (2012) in Thailand; Desoky and Mousa (2012) in Egypt and Macarulla and Talalweh (2012) in Saudi Arabia. However, it is inconsistent with the results reached by Al-Farah and Al-Hindawi (2011) in Jordan; Rouf (2011) in Bangladesh; Hussainey et al. (2011) in Egypt; Andrikopoulos and Kriklani (2013) in Denmark who observed that there is no statistically significant impact of the firm's size on the level of corporate social responsibility disclosure.

It is shown from table 3 that there is positive and significant relationship between the level of corporate social responsibility disclosure and net profit. In other words, firms listed on the KSE with high net profit is likely to disclose more social responsibility reporting than firms with low net profit. The possible explanation for this finding is attributed to the fact that profitable firms have an incentive to convey more social information which is favourable to it as a justification of good news. Moreover, the high profit reflects an indication about the effectiveness of corporate management. This finding is consistent with the results reached by previous empirical studies that reported firms with high profit is likely to have high level of disclosure compared to firms with low profit such as; Saaydah (2005) in Jordan, Bahrain and Kuwait; Hossainet al. (2006) in Bangladesh, Hossain and Hammami (2009) in Qatar; Alawi and Rahman (2011) in Yemen; Macarulla and Talalweh (2012) in Saudi Arabia and Andrikopoulos and Kriklani (2013) in Denmark. However, it is inconsistent with the results reached byGalaniet al. (2011) in Greece who observed that there was no statistically significant impactof the profit on the level of corporate social responsibility disclosure.

Table 3 also demonstrates that there is negative and marginal significant relationship between government ownership and the level of corporate social responsibility disclosure. In other words, firms listed on the KSE with highgovernment ownership are likely to disclose less social responsibility disclosure than firms with a low government ownership.The possible explanation for this finding is attributed to the fact that government is likely to obtain information from easier accesses. Moreover, government can use its power by requesting information directly from company management and that there is no need tovoluntarily disclose social information to other users. This finding is consistent with the results reached by previous empirical studies that reported firms with high proportion government ownership is likely to have a lower level of disclosure compared to companies with low government ownership such as; Elijido-Ten (2004) and Amran and Devi (2007) in Malaysia; Huafang and Jianguo (2007) in China; Ismail and Ibrahim (2009) in Jordan; Hussainey et al. (2011) in Egypt and Al-Janadi et al. (2012) in Saudi Arabia and the UAE.

The study provided no relationship evidence between the industry type and the level of social responsibility reporting. The possible explanation for this finding is attributed to the fact that there is only two sectors namely industry and service. This findings isconsistent with the results reached by Ahmad et al. (2003) in Malaysia, Saaydah (2005) in Jordan, Bahrain and Kuwait, Hussainey et al. (2011) in Egypt who observed that there is not much difference in terms of the level of corporate social responsibility disclosuremade across industrial sectors. However, it is inconsistent with the results reached by previous empirical studies that reported manufacturing firms are likely to have a higher level of disclosure compared to service firms such as Ismail and Ibrahim (2009) in Jordan.

Table 3 also shows that there is negative but not significant relationship between firm's age represented by the length of time a firm has been in business and the level of corporate social responsibility disclosure. In other words, young firms are likely to disclose more social responsibility than old firms. The possible explanation for this finding is attributed to the fact that younger-established firms are expected to establish relationships with prevalent group of stakeholders. With an increase of stakeholders, the need for social responsibility disclosure as a means of communicating with stakeholders increases. This finding is consistent with the results reached by Rettab et al. (2009) and Liu and Anbumozhi (2009) in China who observed that there is negative relationship between firm age and the level of social responsibility reporting.However,it is inconsistent with the results reached by previous empirical studies that reported older firms are likely to have high level of social disclosure compared to younger ones such as; Saaydah (2005) in Jordan, Bahrain and Kuwait, Hossain and Hammami (2009) in Qatar; AL-Shubiri et al. (2012) in Jordan; Bayoud et al. (2012) in Libya and Ahmed (2012) in UAE.

The study provided positive but not significant relationship between firm leverage and the level of corporate social responsibility disclosure. It reveals that high firm's leverage disclose more social responsibility reporting compared to low firm's leverage. The possible explanation for this finding is attributed to the fact that high firms' leverage are inclined to increase disclosure to reduce agency costs between insiders and creditors. In other words, 
the more the firm depends upon debt financing, the more likely it is to disclose more social information in order to be seen as a firm with lower risk. Moreover, lenders seem to pay more attention to these firms' communication about social responsibility. This finding is consistent with the results reached by previous empirical studies that reported firm with high leverage seems to the level of CSED such as Purushotaman et al. (2000) in Singapore, and Kouhy (2008) in UK; Al-Janadi et al. (2013) in Saudi Arabia. However, it is inconsistent with the results reached by Brammer and Pavelin (2006) and Akrout and Othman (2013) in MENA who observed that there is negative relationship between firms with high leverage and the level of corporate social responsibility disclosure.

Furthermore, the study provided negative but not significant relationship between firm liquidity and the level of corporate social responsibility disclosure. It reveals that high firm's liquidity disclose less social responsibility reporting compared to low firm's liquidity.The possible explanation for this finding is attributed to the fact that low firms' liquidity is likely to publish more social responsibility information in their annual reports to satisfy the information requirements of stakeholders. This finding is consistent with the results reached by previous empirical studies that reported firm with lowliquidity seems to disclose high level of social responsibility information such as Aly et al. (2010) who found no association between the two variables. However, it is inconsistent with the results reached by Samaha and Dahawa (2010) provided evidence that there is a positive association between the overall level of voluntary disclosure and liquidity.

\section{Conclusion}

In this study, an attempt was made to investigate the level of corporate social responsibility reporting and factors affecting it by firms listed on KSE. To achieve these objectives, content analysis were used on 2012 annual reports for manufacturing and service sectors. The level of disclosure was calculated by using a disclosure index of 15 disclosure items as a benchmark.

The score of each firm was estimated by dividing its score over the maximum score (15 disclosure item). The extent of disclosure ranged from as low as 0.2 up to 0.8. In other words, the annual reports of some firms contained 20 percent of social responsibility information, whereas the annual reports of other firms contained 80 percent of the maximum disclosure score. The mean score of all firms, however, was only 0.48 percent as an evidence that the level of social responsibility disclosure was relatively low. Therefore, it was important to identify the relationship between the level of social responsibility disclosure and firm's attributes. There are various firm's attributes which was gathered from previous studies and used in the current study. The attributes are profitability, liquidity, leverage, industry type, firm's age, percentage of shares owned by the government and size represented by total sales.

Regression analysis demonstrated that there is a positive and significant relationship between the level of social disclosure and firm size and profitability. It revealed that large firms in terms of total sales and net income disclose more social responsibility compared to small firms. It means that large and profitability firms are thoroughly analyzed by public opinion and governments, which have motivated them to disclose a higher volume of social information. This finding seems to support the agency and political theories that state large and profitable firms are more observable to the public as well as to the pressure groups. As a result, they are subjected to more political pressure than other firms. Therefore, as an attempt to reduce checking cost and to political pressure, these firms are more likely to voluntary disclose social responsibility information.

The study also documented a negative and marginally significant disclosure between the level of social responsibility disclosure and the percentage of shares owned by the government. This result is not surprising since government can use its power by requesting information directly from firm management and that there is no need to voluntarily disclose social information to other users.

In short, the contribution of the study is that firms listed in industrial and service sectors on KSE are affected by their size and profitability to disclosure social responsibility and there is a long avenue to develop and enhance the level of social responsibility reporting. The current study focused on manufacturing and service sectors, the findings may not generalize to other sectors. However, it is interesting for scholars in Kuwait to examine why some firms do not disclose such information in their annual reports.

\section{Acknowledgments}

This work was supported by a grant from the Arab Open University-Kuwait branch. The authors would like to express their special tokens of gratitude to the research committee for its support and guidance. Special thanks to our academic colleagues for their constructive criticism and friendly advice during the paper work.

\section{References}

Abu-Baker, N. (2000). Corporate social reporting and disclosure practice in Jordan: An empirical investigation. 
Administrative Sciences, Dirasat Journal, 27(1), 249-263.

Ahmad, N., \& Mousa, F. (2010). Corporate environmental disclosure in Libya: A little improvement. World Journal of Entrepreneurship, Management and Sustainable Development, 6(1/2), 149-159.

Ahmad, N., \& Sulaiman, M. (2004). Environmental disclosures in Malaysian annual reports: A legitimacy theory. International Journal of Commerce \& Management, $14(1), \quad 44-58$. http://dx.doi.org/10.1108/10569210480000173

Ahmad, N., Sulaiman, M., \& Siswantoro, D. (2003). Corporate social responsibility disclosures in Malaysia: An analysis of annual reports of KLSE listed companies. Journal of Economics and Management, 11(1), 1-37.

Ahmed, I. (2012). The contents of social disclosure: A survey of the UAE Islamic banks' reports. Journal of Management Studies, 5(1). Retrieved from http://ejournals.uofk.edu/index.php/kujms/article/view/142/159

Akrout, M., \& Othman, H. (2013). A study of the determinants of corporate environmental disclosure in MENA emerging markets. Journal of Reviews on Global Economics, 2, 46-59. http://dx.doi.org/10.6000/19297092.2013.02.5

Alawi, N., \& Rahman, A. (2011). Corporate social responsibility disclosure in response to CSR ward with the moderating effect of family group affiliation in Yemen. Retrieved from http://www.unirazak.edu.my/colloquium2011/eproceedings/1.\%20FIN-Nahg_Alawi.pdf

Alenezi, F. (2011). Composition of corporate board of directors and voluntary disclosure in the annual reports: The case of Kuwait. Arab Journal of Administrative Sciences, 18(1), 135-163.

Al-Farah, A., \& Al-Hindawi, R. (2011). The corporate social responsibility disclosure: The case of industrial public shareholding companies listed in the Amman Stock Exchange for the years 2007-2008. Jordan Journal of Business Administration, 7(2), 273-293.

Al-Janadi, Y., Abdul Rahman, R., \& Omar, N. (2012). The level of voluntary disclosure practices among public listed companies in Saudi Arabia and the UAE: Using a modified voluntary disclosure index. International Journal of Disclosure and Governance, 9(May), 181-201. http://dx.doi.org/10.1057/jdg.2011.19

Al-Janadi, Y., Abdul Rahman, R., \& Omar, N. (2013). Corporate governance mechanisms and voluntary disclosure in Saudi Arabia. Research Journal of Finance and Accounting, 4(4), 25-35.

Al-Khadash, H. (2004). The accounting disclosure of social and environmental activities a comparative study for the industrial Jordanian shareholding companies. Abhath Al-Yarmook Journal, 20(1b), 21-39.

Al-Matarnah, G. H. (2008). The extent of Jordanian shareholding industrial companies adherence to environmental performance accounting disclosure: Field study. AlEdari, 113(June), 149-178.

Al-Shammari, B. (2008). Voluntary disclosure in Kuwait corporate annual reports. Review of Business Research, $8(1), 62-81$.

AL-Shubiri, F., Al-Abedallat, A., \& Abu Orabi, M. (2012). Financial and non-financial determinants of corporate social responsibility. Asian Economic and Financial Review, 2(8), 1001-1012.

Alturki, K. H. (2014). Voluntary disclosure by Saudi companies. Research Journal of Finance and Accounting, 5(20), 77-94.

Aly, D., Simon, J., \& Hussainey, K. (2010). Determinants of corporate internet reporting: Evidence from Egypt. Managerial Auditing Journal, 25(2), 182-202. http://dx.doi.org/10.1108/02686901011008972

Amran, A., \& Devi, S. (2007). Corporate social reporting in Malaysia: A political theory perspective. Malaysian Accounting Review, 6(1), 19-44.

Ayadi, S. (2004). Determinants of the corporate decision to disclose stakeholders' reports in France. 27th annual congress of the European Accounting Association, 2004, Prague, Czech Republic. European Accounting Association, pp. 1-28.

Bayoud, N., Kavanagh, M., \& Slaughter, G. (2012). Factors influencing levels of corporate social responsibility disclosure by Libyan firms: A mixed study. International Journal of Economics and Finance, 4(4), 13-29. http://dx.doi.org/10.5539/ijef.v4n4p13

Binh, Q. (2012). Voluntary disclosure information in the annual reports of non-financial listed companies: The case of Vietnam. Journal of Applied Economics and Business Research, 2(2), 69-90.

Brammer, S., \& Pavelin, S. (2006). Corporate reputation and social performance: The importance of fit. Journal 
of Management Studies, 43(3), 435-455. http://dx.doi.org/10.1111/j.1467-6486.2006.00597.x

Deegan, C., \& Jeffry, U. (2006). Financial accounting theory. Berkshire SL6 2QL, McGraw-Hill Education.

Desoky, A., \& Mousa, G. (2012). Corporate governance practices: Transparency and disclosure-evidence from the Egyptian exchange. Journal of Accounting, Finance and Economics, 2(1), 49-72.

Dowling, J., \& Pfeffer, J. (1975). Organizational legitimacy social values and organizational behavior. Pacific Sociological Review, 18(1), 122-136. http://dx.doi.org/10.2307/1388226

Ebimobowei, A. (2011). A study of social accounting disclosures in the annual reports of Nigerian companies. Asian Journal of Business Management, 3(3), 145-151.

Echave, J., \& Bhati, S. (2010). Determinants of social and environmental disclosures by Spanish companies. GSMI Third Annual International Business Conference (pp. 55-68). Michigan, USA: Global Strategic Management Inc.

Elijido-Ten, E. (2004). Determinants of environmental disclosures in a developing country: An application of the stakeholder theory. Presentation at the Fourth Asia Pacific Interdisciplinary Research in Accounting Conference, 4 to 6 July 2004, Singapore.

Haque, S. (2012). Corporate social responsibility: A comprehensive framework-Bangladesh perspective. European Journal of Social Sciences, 36(2), 220-229.

Hossain, M., \& Hammami, H. (2009). Voluntary disclosure in the annual reports of an emerging country: The case of Qatar. Advances in Accounting, Incorporating Advances in International Accounting, 25(2), 255265. http://dx.doi.org/10.1016/j.adiac.2009.08.002

Hossain, M., Islam, K., \& Andrew, J. (2006). Corporate social and environmental disclosure in developing countries: Evidence from Bangladesh. In Proceedings of the Asian Pacific Conference on International Accounting Issues, Hawaii, October 2006.

Huafang, X., \& Jianguo, Y. (2007). Ownership structure, board composition and corporate voluntary disclosure. Managerial Auditing Journal, 22(6), 604-619. http://dx.doi.org/10.1108/02686900710759406

Hussainey, K. H., Elsayed, M., \& Razik, M. (2011). Factors affecting corporate social responsibility disclosure in Egypt. Corporate Ownership and Control Journal, 8(4), 432-443.

Islam, M., \& Islam, A. (2011). Environmental incidents in a developing country and corporate environmental disclosures: A study of a multinational Gas company. Society and Business Review, 6(3), 229-248. http://dx.doi.org/10.1108/17465681111170984

Ismail, K., \& Ibrahim, A. (2009). Social and environmental disclosure in the annual reports of Jordanian companies. Issues in Social and Environmental Accounting, 2(2), 198-210.

Jahamani, Y. (2003). Green accounting in developing countries: The case of U.A.E and Jordan. Managerial Finance, 29(8), 37-45. http://dx.doi.org/10.1108/03074350310768418

Joshi, P., Suwaidan, M., \& Kumar, R. (2011). Determinants of environmental disclosures by Indian industrial listed companies in their Websites: Empirical study. International Journal of Accounting and Finance, 3(2), 109-130. http://dx.doi.org/10.1504/IJAF.2011.043843

Juhmani, O. (2014). Determinants of corporate social and environmental disclosure on websites: The case of Bahrain. Universal Journal of Accounting and Finance, 2(4), 77-87.

Khasharmeh, H., \& Suwaidan, M. (2010). Social responsibility disclosure in corporate annual reports: Evidence from the Gulf Cooperation Council countries. International Journal of Accounting, Auditing and Performance Evaluation, 6(4), 327-345. http://dx.doi.org/10.1504/IJAAPE.2010.036150

Lassaad, B., \& Khamoussi, H. (2012). Environmental and social disclosure and earnings persistence. International Journal of Social Science \& Interdisciplinary Research, 1(7), 20-42.

Liu, X., \& Anbumozhi, V. (2009). Determinant factors of corporate environmental information disclosure: An empirical study of Chinese listed companies. Journal of Cleaner Production, 17, 593-600. http://dx.doi.org/10.1016/j.jclepro.2008.10.001

Macarulla, F., \& Talalweh, M. (2012). Voluntary corporate social responsibility disclosure: A case study of Saudi Arabia. Jordan Journal of Business Administration, 8(4), 815-830. 
Mbekomize, C. H., \& Dima, L. (2013). Social and environmental disclosure by parastatals and companies listed on the Botswana Stock Exchange. Journal of Management and Sustainability, 3(3), 66-75. http://dx.doi.org/10.5539/jms.v3n3p66

Motta, R. (2003). Determinants of environmental performance in the Brazilian industrial sector. Research Institute of Applied Economics (IPEA). Retrieved from http://siteresources.worldbank.org/NIPRINT/Resources/DeterminantsofEnvironmentalPerformanceintheBra zilianIndustrialSector.pdf

Naser, K., \& Hassan, Y. (2013). Determinants of corporate social responsibility reporting: Evidence from an emerging economy. Journal of Contemporary Issues in Business Research, 2(3), 56-74.

Naser, K., Al-Hussaini, A., Al-Kwari, D., \& Nuseibeh, R. (2006). Determinants of corporate social disclosure in developing countries: The case of Qatar. Advances in International Accounting, 19, 1-23. http://dx.doi.org/10.1016/S0897-3660(06)19001-7

Owusu-Ansah, S. (1998). The impact of corporate attributes pm the extent of mandatory disclosure and reporting by listed companies in Zimbabwell. The International Journal of Accounting, 33, 605-631. http://dx.doi.org/10.1016/S0020-7063(98)90015-2

Papaspyropoulos, K., Blioumis, V., \& Christodoulou, A. (2010). Environmental reporting in Greece: The Athens stock exchange. African Journal of Business Management, 4(13), 2693-2704.

Rahahleh, M., \& Adel Sharairi, J. (2008). The extent of social responsibility accounting application in the qualified industrial zones in Jordan. International Management Review, 4(2), 5-17.

Rettab, B., Brik, A., \& Mellahi, K. (2009). A study of management perceptions of the impact of corporate social responsibility on organisational performance in emerging economies: The case of Dubai. Journal of Business Ethics, 89(3), 371-390. http://dx.doi.org/10.1007/s10551-008-0005-9

Rizk, R., Dixon, R., \& Woodhead, A. (2008). Corporate social and environmental reporting: A survey of disclosure practices in Egypt. Social Responsibility Journal, 4(3), 306-323. http://dx.doi.org/10.1108/17471110810892839

Rouf, A. (2011). Corporate characteristics, governance attributes and the extent of voluntary disclosure in Bangladesh. African Journal of Business Management, 5(19), 7836-7845.

Saaydah, M. (2005). Corporate social disclosures in some Arab countries: A comparison among Jordan, Bahrain and Kuwait. Administrative Sciences, Dirasat Journal, 32(2), 435-453.

Samaha, K., \& Dahawy, K. (2010). Factors influencing voluntary corporate disclosure by the actively traded Egyptian firms. Research in Accounting in Emerging Economies, 10, 87-119.

Suttipun, M., \& Stanton, P. (2012). Determinants of environmental disclosure in Thai corporate annual reports. International Journal of Accounting and Financial Reporting, 2(1), 99-115. http://dx.doi.org/10.5296/ijafr.v2i1.1458

Ullmann, A. (1985). Data in search of a theory: A critical examination of the relationships among social performance, social disclosure, and economic performance of U.S. firms. Academy of Management Review, 10(3), 540-557. http://dx.doi.org/10.5465/amr.1985.4278989

Uwalomwa, U., \& Uadiale, O. (2011). Corporate social and environmental disclosure in Nigeria: A comparative study of the building material and brewery industry. International Journal of Business and Management, 6(2), 258-264. http://dx.doi.org/10.5539/ijbm.v6n2p258

Uwuigbe, U. (2012). Web-Based corporate environmental reporting in Nigeria: A study of listed companies. Informatica Economică, 16(3), 27-36.

Wang, J., Hsiung, H., \& Ku, W. (2012). Ownership structure and environmental disclosure: Taiwan evidence. International Research Journal of Finance and Economics, 88(April), 132-145.

Watts, R., \& Zimmerman, J. (1983). Agency problems, auditing and theory of the firm: Some evidence. Journal of Law \& Economics, 12(26), 613-633. http://dx.doi.org/10.1086/467051

Zamir, F., Awan, T., \& Hasan, A. (2011). Comparison of financial and nonfinancial environmental reporting. Interdisciplinary Journal of Contemporary Research in Business, 3(8), 346-373. 


\section{Notes}

Note 1. see for example, Jordan: Abu-Baker, 2000; Al-Khadash, 2004; Al-Matarnah, 2008; Rahahleh \& Adel Sharairi, 2008; Ismail \& Ibrahim, 2009; Al-Farah \& Al-Hindawi, 2011; AL-Shubiri et al., 2012; Naser \& Hassan, 2013. Bangladesh: Hossain et al., 2006; Islam \& Islam, 2009; Haque, 2012. South Africa: Barnard, 2000. Brasília: Motta, 2003. Malaysia: Ahmad et al., 2003; Elijido-Ten, 2004; Amran \& Devi, 2007. China: Huafang \& Jianguo, 2007; Liu \& Anbumozhi, 2009. Spain: Echave \& Bhati, 2010. Greece: Papaspyropoulos et al., 2010; Galani et al., 2011. India: Joshi et al., 2011. Yemen: Alawi \& Rahman, 2011. Pakistan and UK: Zamir et al., 2011. Nigeria: Ebimobowei, 2011; Uwalomwa \& Uadiale, 2011; Uwuigbe \& Jimoh, 2012; Uwuigbe, 2012. Taiwan: Wang et al., 2012. France: Ayadi, 2004; Lassaad \& Khamoussi, 2012. Thai: Suttipun \& Stanton, 2012; Vietnam: Binh, 2012. Egypt: Rizk et al., 2008; Desoky \& Mousa, 2012; Hussainey et al., 2011. Romania: Alin, 2012. Libya: Ahmad \& Mousa, 2010; Bayoud et al., 2012. Indonesia: Setyorini \& Ishak, 2012. Denmark: Andrikopoulos \& Kriklani, 2013. Botswana: Mbekomize \& Dima, 2013. Arab Countries: Akrout \& Othman, 2013).

Note 2. see for example, Bahrain: Gibbon \& Joshi, 1999; Juhmani, 2014. Jordan, Bahrain \& Kuwait: Saaydah, 2005. Kuwait: Al-Shammari, 2008; Alenezi, 2011. Qatar: Naser et al., 2006; Hossain \& Hammami, 2009. Saudi Arabia: Macarulla \& Talalweh, 2012; Alturki, 2014. United Arab Emirates (UAE): Rettab et al., 2009; Ahmed, 2012. Saudi Arabia and the UAE: Jahamani, 2003; Al-Janadi et al., 2012; GCC: Khasharmeh \& Suwaidan, 2010.

\section{Copyrights}

Copyright for this article is retained by the author(s), with first publication rights granted to the journal.

This is an open-access article distributed under the terms and conditions of the Creative Commons Attribution license (http://creativecommons.org/licenses/by/3.0/). 